the owner. The portrait of Harvey was fraudulently exported to the United States, where it was sold. Those responsible wero heavily fined in a magistratos' court in January 1962.

Fvon though the portrait is of spocial intorest in that it shows William Harvey as he was during the period ho was compiling his lecture notes, it would have boen more tactful not to have flaunted it so blatantly with attributions to its present American domicile and ownership in a book touching so very closely on the Royal College in which Harvey delivered his lecturos and which has so recently suffered tho ignominious loss of the portrait.

Ressell Brock

\section{ANTOINE FRANÇOIS DE FOURCROY}

\section{Fourcroy}

Chemist and Revolutionary 1755-1809. By W. A. Smeaton. Pp. xxi $+288+7$ plates. (Cambridgo: W. Heffer and Sons, Ltd., 1962.) 40s.; 6.00 dollars.

$\mathrm{T}$ HIS book is the kind of foundation on which the history of chemistry will eventually be built. There are many volumes of laborious detail in which the wood cannot be seen for trees, and many full of enticing generalizations which serious research can easily disprove; but there are not many like this on $\mathrm{w}$ wich combines thorough scholarship with a grasp of how the particular subject fits into the general picture. It is common to find the history of chemistry presented in isolation, without reference to the industry, politics, society or educational system around it. Yot chemists are cortainly not cut off from the world, and this book has the great merit of showing the life of a distinguished chomist as a whole, with all his varied activities and their influence on his sciontific work.

Fourcroy is, indeed, a particularly attractive subject-. active both in chemical rosearch at the crisis of the chemical revolution and in politics in the France of Robespierro and Napoleon. His election to the Convention seems to have been against his will, but he served on it and on the Committee of Public Instruction during the Terror, and then on the Committee of Public Safety, roturning after an interval to serve on the Council of State under Bonaparte. As the director-general of public instruction who planned the Imperial University to control all education he might well have become its first Grand Master, but was rejected probably because the Emporor nooded the Church's co-operation, and Fourcroy was a froethinker. (So was the Emperor, unofficially.)

Fourcroy has often been held responsible for Lavoisier's execution, or at least for not having done all he could to save him. Dr. Smeaton argues, however, that the evidence on which Lavoisier was condemned was the same as that against all the Farmors-General of Taxes, and shows that Fourcroy actually riskod his lifo in speaking for Lavoisier at a meeting of the Committee of Public Safety, to which ho had then no right of entry. Thero is no proof that the incriminating lottors found among Lavoisier's papers, which havo been published by Prof. McKie, were over reported to the authorities.

Unfortunatoly, little is known of Fourcroy's private lifo and character, and tho author will no doubt be criticized for not having 'brought his subject to life'. Howover, it is not a scholar's part to produce imaginativo reconstructions without evidence. What he does bring to life most vividly is the world of chomical toaching and research in which Fourcroy was a leader. To understand the processes of formation of scientific theory, it is necessary to understand not only the few contemporary idoas which have survived but also all the concepts and attitudes, since forgotten, which seomed important at the time and were the context in which advances were made. It is in this that the author is particularly successful.
Fourcroy was a distinguished teacher and writor of text-books, and did valuable work, generally in collaboration with Vauquolin, on plant and animal chemistry, the application of chemistry to medicine, and on inorganic salts. He produced what may have boen the oarliest systematic scheme of inorganic analysis, and, like most French chemists of the time, was often called on to apply his knowlodgo for practical uses. This book, which has good indexes, notes and copious bibliography, will cer. tainly become the standard work on its subject.

\section{A. M. DUNCAN}

\section{GEOPHYSICAL SCIENCES}

Applied Geophysics U.S.S.R.

Edited by Dr. Nicholas Rast. Pp. 429. (London and New York: Porgamon Pross, 1962.) 100s. net.

Fundamental Problems in Turbulence and Their Relation to Geophysics

Procoedings of a Symposium held at the Faculty of Sciences and at the Institut de Mécanique Statistique de la Turbulence of the University of Aix-Marseillo, September 4-9, 1961, Marseilles, France. Edited by Francoise N. Frenkiel. (Intornational Union of Geodesy and Geophysies and International Union of 'Theoretical and Applied Mechanies. Reprinted from the Journal of Geophysical Research, Vol. 67, No. 8.) Pp. iv +234 . (Washington, D.C.: American Geophysical Union, 1962.) 5 dollars.

Earth, Sea, and Air

A Survey of the Geophysical Sciences (Addison-Wesley Series in the Earth Sciences.) By Prof. Jorome Spar. Pp. vii + 152. (Reading, Massachusetts and London: Addison-Wesley Publishing Co., Inc., 1962.) Paporback 14s.; Hardbound $23 s$.

$\mathrm{W}^{\mathrm{y}}$ E still know too little about geophysical studies in the U.S.S.R., and Dr. Rast's translation of a selection of Soviet papers on applied goophysies is to be welcomed. There are four papers on seismic methods, two on gravity, fivo on electrical mothods and six on bore-hole logging methods. Undoubtedly, the most, useful articles for Western readers concern the mothods of electrical prospecting, on which the literature in Wostern countries is sparse.

The papers presented at a symposium held in Marseillos during September 4-9, on "Fundamental Problems in Turbulence and Their Relation to Geophysies", and originally published in tho Journal of Geophysical Research. have now been published togethor in book form under the editorship of F. N. Frenkiel. The valuo of this publication noed scarcely be emphasized.

Earth, Sea, and Air is a survoy of geophysies intended for a course in a liberal arts college in the United States. Prof. Spar foels that the arts man noeds some knowlodge of science if he is to be effoctive in the teaching or administrative work in which he will later be engaged. This notion is, of course, still quite foreign to the Finglish university or to the grammar or public school sixth-form on the modern or classical side. 'The book is quite a good one, emphasizing well the exciting human quest which any seiontific field, if treatod historically, reprosents. It would be an interesting oxperiment to use such a book as the basis of a courso in an arts department of an Finglish university.

Slightly irritating Americanisms crop up; for example. on $p .41$ we read of the founder of geology William (Strata) Smith. It is also rather out of date and treats as an articlo of faith that the Earth was once molten, but then almost every geologist believes this. in spite of strong geophysical and geochemical ovidenco to the contrary, This, howover, is poetic justice, as geologists are fond of 